\title{
Nip New Disease Reports \\ First report of potato blackleg caused by a biovar 3 Dickeya sp. in Georgia
}

\author{
L. Tsror [Lahkim] ${ }^{1} *$, O. Erlich ${ }^{1}$, S. Lebiush ${ }^{1}$, J. van der Wolf ${ }^{2}$, R. Czajkowski ${ }^{2}$, G. Mozes $^{3}$, Z. Sikharulidze $^{4}$ and B. Ben
} Daniel $^{1}$

${ }^{1}$ Agricultural Research Organization, Gilat Research Center, Dep of Plant Pathology and Weed Research, MP Negev 85280 , Israel ; ${ }^{2}$ Plant Research International, P.O. Box 16, 6700 AA Wageningen, the Netherlands ; ${ }^{3}$ Kibbutz Nir Oz, Israel ; ${ }^{4}$ Institute of Phytopathology of Georgia, 6200, Kobuleti, Georgia

*E-mail: tsror@volcani.agri.gov.il

Received: 19 Jul 2010. Published: 12 Jan 2011.

In Western and Northern Europe, Dickeya species are causing increasingly severe economic losses in potato (Solanum tuberosum) crops. The costs of seed potato production resulting from Dickeya spp. infection are high due to rejection and declassification of seed tubers (Sławiak et al., 2009). Potato blackleg caused by Dickeya spp. is primarily a seed tuber-borne disease (Tsror et al., 2009). Symptoms including blackening of the stem base, wilting of plants and rotten seed tubers are observed. Recently, outbreaks of potato blackleg were recorded in Georgia on three cultivars, in Samtskhe-Javakheti region, Akhalkalaki district, in an area in excess of 100 hectares.

During the spring of 2008, samples of potato plants with symptoms of blackleg, wilting and soft rots, and their daughter tubers, were sent to Israel for detection of potential infection with Dickeya spp. Representative samples were collectedfrom Akhalkalaki district, Georgia (cvs. Picasso, Milva and Jelly, the origin of the seed tubers being the Netherlands and Germany). Plant material was surface sterilised with hypochlorite. Ten segments from the stem base of each plant or a tissue sample from the stolon end (including both the vascular bundles and the peel) of each tuber were removed, using a sterile scalpel and homogenized with $10 \mathrm{ml}$ sterile distilled water. Sample homogenates were plated on crystal violet pectate medium (CVP). Cavity forming bacteria were transferred to nutrient agar and analysed. DNA extracted from bacteria of all samples was positive in PCR amplification using pelADE specific primers which are specific for $E$. chrysanthemi (Nassar et al., 1996), corresponding to the newly-described genus Dickeya. Isolates were identified by biochemical assays as biovar 3 (Palacio-Bielsa et al, 2006). They were characterised as the new genetic clade, using REP-PCR analysis (Tsror et al., 2009) and dnaX sequence (Stawiak et al., 2009) (GenBank Accession No. HQ678686). These isolates caused maceration of potato tubers at $30^{\circ} \mathrm{C}$ (Laurila et al., 2008) and formed clear haloes on a polygalacturonic acid medium (Collmer $e t$ al., 1988). During the winter of 2009, samples of 200 progeny tubers from the same region in Georgia (cvs. Picasso, Milva and Jelly) were shipped to Israel fordetection of latent infection by Dickeya spp. Stolon ends were removed from tubers, placed in polypectate enrichment broth and incubated for $48 \mathrm{~h}$. DNA extracted only from bacterial pellets from cv. Picasso were positive in PCR amplification using pelADE specific primers. To the best of our knowledge this is the first report on the presence of
Dickeya sp. on potato in Georgia, indicating the dissemination of this pathogen in Europe.

\section{References}

Collmer A, Ried JL, Mount MS, 1988. Assay methods for pectic enzymes. Methods in Enzymology. 161, 329-335.

Laurila J, Ahola V, Lehtinen A, Joutsjoki T, Hannukkala A, Rahkonen A, Pirhonen M, 2008. Characterization of Dickeya strains isolated from potato and river water samples in Finland. European Journal of Plant Pathology. 122, 213-225. [doi:10.1007/s10658-008-9274-5]

Nassar A, Darrasse A, Lemattre M, Kotoujansky A, Dervin C, Vedel R, 1996. Characterization of Erwinia chrysanthemi by pectinolytic isoenzyme polymorphism and restriction fragment length polymorphism analysis of PCR-amplified fragments of pel genes. Applied and Environmental Microbiology. 62, 2228-2235.

Palacoi-Bielsa J, Cambra MA, Lopez MM, 2006. Characterisation of potato isolates of Dickeya chrysanthemi in Spain by a microtitre system for biovar determination. Annals of Applied Biology. 148, 157-164. [doi:10.1111/j.1744-7348.2006.00045.x]

Sławiak M, van Beckhoven JRCM, Speksnijder AGCL, Czajkowski R, Grabe G, van der Wolf JM, 2009. Biochemical and genetical analysis reveal a new clade of biovar 3 Dickeya spp. strains isolated from potato in Europe. European Journal of Plant Pathology. 125, 245-261. [doi:10.1007/s10658-009-9479-2]

Tsror (Lahkim) L, Erlich O, Lebiush S, Hazanovsky M, Zig U, Sławiak M, Grabe G, van der Wolf JM, van de Haar JJ, 2009. Assesment of recent outbreaks of Dickeya sp. (syn. Erwinia chrysanthemi) slow wilt in potato crops in Israel. European Journal of Plant Pathology. 123, 311-320. [doi:10.1007/s10658-008-9368-0]

To cite this report: Tsror [Lahkim] L, Erlich O, Lebiush S, van der Wolf J, Czajkowski R, Mozes G, Sikharulidze Z, Ben Daniel B, 2011. First report of potato blackleg caused by a biovar 3 Dickeya sp. in Georgia. New Disease Reports 23, 1. [doi:10.5197/j.2044-0588.2011.023.001] 